\title{
PERBEDAAN EFEKTIVITAS PEMBERIAN PUTIH TELUR DAN IKAN GABUS TERHADAP PENYEMBUHAN LUKA PERINEUM IBU NIFAS
}

\author{
Weni Tri Purnani \\ Prodi Kebidanan, Fakultas Ilmu Kesehatan, Universitas Kadiri \\ tripurnani0330@gmail.com
}

\begin{abstract}
Perineal injury is caused by the birth canal laceration or an indicated of episiotomy when the mother deliveries the baby. Late of healing the perineal injury was increased the risk of infection, so it needs nutrision intake especially protein to support the growth of new generation cells around the wound. The purpose of this study was to determine the differences in the speed of wound healing between consumption of egg whites and corkfish to post partum mother.The research design was pre experiment with one-shot case study. The population is all the postpartum mothers who had ruptured perineum. Samples were taken with purposive sampling technique, with total respondent 32 people. Data were collected using instruments of data collection sheets and sheets of observations. The data were analyzed using the Wilcoxon and Mann Whitney test and the result was presented to frequency distribution table form.The results of Mann Whitney test as evidenced by the value of $Z=-2.626$; $\rho=$ 0.009; $\alpha=0.05 ; \rho<\alpha$, then $H_{0}$ rejected and $H_{1}$ accepted. It means that there is a difference between the influence of egg whites and fish cork to the phase of perineal wound healing of post partum mother. Egg whites is more effective than fish cork in healing woundv of the perineum. Based on the result of the research study, it is expected to give a beneficial contribution in improing education about the advantage of egg white and fish cork to enhance the health status of post partum mother.
\end{abstract}

Keywords: perineal wound healing, egg whites, fish cork

\begin{abstract}
ABSTRAK
Luka perineum adalah luka pada perineum karena adanya robekan jalan lahir maupun karena episiotomi pada waktu melahirkan janin. Penyembuhan luka perineum yang lambat dapat meningkatkan resiko terjadinya infeksi, sehingga diperlukan asupan nutrisi khususnya protein yang mendukung pertumbuhan sel baru pada luka perineum. Tujuan penelitian ini untuk mengetahui perbedaan kecepatan penyembuhan luka perineum dengan pemberian putih telur dan ikan gabus pada ibu nifas.Rancangan penelitian yang digunakan dalam penelitian ini adalah pre eksperimen dengan one-shot case study. Populasi penelitian adalah seluruh ibu nifas yang mengalami ruptur perineum. Sampel diambil dengan teknik random simple sampling, dengan responden berjumlah 32. Data dikumpulkan menggunakan instrumen lembar pengumpulan data dan lembar observasi. Variabel bebas dalam penelitian ini adalah pemberian putih telur dan pemberian ikan gabus, variable terikat dalam penelitian ini adalah penyembuhan luka perineum. Analisis data dengan UjiMann Whitney.Hasil uji Mann Whitney diperoleh $Z=-2,626 ; \rho=0,009$ berarti terdapat perbedaan efektivitas pemberian putih telur dan ikan gabus terhadap penyembuhan luka perineum. Putih telur lebih cepat jika dikonsumsi untuk penyembuhan luka perineum. Dengan demikian diharapkan tenaga kesehatan dapat memberikan konseling tentang manfaat putih telur dan ikan gabus secara maksimal sehingga status kesehatan ibu nifas semakin baik.
\end{abstract}

Kata kunci : penyembuhan luka perineum, putih telur, ikan gabus 


\section{PENDAHULUAN}

Masa nifas juga merupakan masa pemulihan organ-organ reproduksi yang mengalami perubahan selama kehamilan dan persalinan, seperti terjadinya robekan perineum. Hal tersebut sering terjadi pada semua persalinan pertama, namun tidak jarang pada persalinan berikutnya, sehingga diperlukan perawatan yang intensif untuk mempercepat proses penyembuhan dan mencegah komplikasi infeksi yang dapat diakibatkan karena keterlambatan penyembuhan luka perineum (Setyowati et al., 2014).

Prevalensi menunjukkan bahwa bagi ibu bersalin yang mengalami rupture perineum di Indonesia sebesar $24 \%$ pada golongan umur 25-30 tahun, sedangkan pada golongan umur 32-39 tahun sebesar 62 persen (Winarti, 2013). Berdasarkan data di Jawa Timur angka kejadian ruptur perineum pada tahun 2008 sebanyak 52 kasus, tahun 2009 sebanyak 18 kasus, tahun 2010 sebanyak 17 kasus, tahun 2011 sebanyak 100 kasus, tahun 2012 sebanyak 93 kasus (Dwi, 2014).

Berdasarkan survey awal yang dilaksanakan di BPM "S" Kabupaten Kediri diperoleh data bulan Januari sampai Maret 2017 terdapat 43 ibu post partum, 15 (34,9\%) primipara dan $28(65,1 \%)$ multipara. 33 $(76,7 \%)$ orang mengalami robekan perineum, $11(33,3 \%)$ orang primipara dan $22(66,7 \%)$ orang multipara. Dari survey yang dilakukan sejak 7 sampai 21 Maret 2016, diperoleh 8 ibu post partum yang mengalami robekan perineum, $3(37,5 \%)$ diantaranya mengalami keterlambatan penyembuhan luka (sembuh lebih dari 7 hari), sedangkan $5 \quad(62,5 \%)$ orangmengalami penyembuhan luka perineum yang normal dimana luka sembuh antara 6 sampai 7 hari. Hal ini berarti masih ada masalah keterlambatan penyembuhan luka perineum pada ibu post partum di BPM "S" Kabupaten Kediri.

Secara fisiologis luka perineum akan mulai membaik dalam waktu 6 hingga 7 hari post partum. Penyebab keterlambatan penyembuhan luka perinuem yaitu pengetahuan ibu yang kurang tentang penyembuhan luka dimana ibu takut melakukan mobilisasi lebih dini, faktor budaya yang sudah melekat sejak dulu sering dijadikan patokan selama masa nifas seperti halnya pantangan terhadap beberapa makanan tertentu dan lebih pada individu itu sendiri diantaranya, malnutrisi serta keadaaan lingkungan yang kurang bersih. Secara umum ada 2 faktor yang mempengaruhi penyembuhan luka perineum meliputi faktor internal dan faktor eksternal. Faktor internal meliputi gizi, personal hygiene, kondisi ibu, keturunan, usia, hemoragi, hipovolemi, faktor lokal edema, defisit nutrisi, defisit oksigen, over aktivitas. Sedangkan faktor eksternal meliputi lingkungan, tradisi, pengetahuan, sosial, ekonomi, penanganan petugas, penanganan jaringan dan obat-obatan (Nugroho, 2014).

Dampak keterlambatan penyembuhan luka perineum yang pertama adalah terjadinya infeksi, kondisi perineum yang terkena lochea dan lembab akan sangat menunjang perkembangan bakteri yang dapat menyebabkan timbulnya infeksi pada perineum. Yang kedua terjadi komplikasi, munculnya infeksi pada perineum dapat merambat pada saluran kandung kemih ataupun pada jalan lahir yang dapat berakibat pada munculnya komplikasi infeksi kadung kemih maupun infeksi pada jalan lahir. Infeksi nifas yang dapat terjadi sebagai akibat komplikasi luka perineum antara lain metritis, endometritis, peritonitis bahkan sampai abses perlvik. Ketiga, adalah terjadinya kematian ibu post partum, apabila terjadi penanganan yang lambat terhadap ibu post partum maka hal ini dapat berpotensi menyebabkan kematian, hal ini karena kondisi fisik ibu post partum masih lemah (Ambarwati dan Wulandari, 2010).

Proses untuk mempercepat penyembuhan luka perineum terdapat beberapa cara, salah satunya adalah melalui perbaikan gizi dengan mengkonsumsi makanan tinggi kalori dan protein. Sumber umum protein adalah daging, susu, roti, sereal, telur, ikan, kacang-kacangan dan biji-bijian (Mauren, 2008). Ikan gabus (Channa striata) merupakan salah satu jenis ikan yang dapat meningkatkan daya tahan tubuh karena mengandung protein dan albumin yang tinggi. Daging ikan gabus mengandung $70 \%$ protein dan $21 \%$ albumin. Di samping itu, daging ikan gabus juga mengandung asam amino yang lengkap serta mikronutrien zinc, selenium dan iron. Kandungan lain dalam daging ikan gabus adalah alisin, alil sulfide dan furostanol glikosida (Suprayitno, 2003).

Protein dan albumin sangat berfungsi sebagai zat pembangun sel-sel yang telah rusak sehingga penyembuhan luka akan berlangsung lebih cepat. Dengan tingginya kandungan 
protein dan albumin, ikan gabus kemungkinan dapat digunakan oleh masyarakat untuk proses penyembuhan luka terutama luka pasca operasi, luka bakar dan setelah persalinan. Salah satu jenis makanan yang mengandung banyak protein adalah putih telur. Orang juga banyak menghindari telur karena khawatir dengan kandungan kolesterolnya yang tinggi. Kandungan kolesterol yang tinggi hanya terkonsentrasi di kuning telur, sedangkan pada putih telur bebas dari kolesterol sehingga aman untuk dikonsumsi. Putih telur sangat kaya protein, bebas lemak dan kolesterol (berbeda dengan kuning telur). Kandungan protein ini sangat bermanfaat sebagai zat pembangun dalam tubuh. Kandungan yang terdapat dalam putih telur berupa protein. Kandungan lainnya yang terdapat dalam putih telur seperti vitamin A, D, E, K, B2, B5, B9 dan juga B12. Putih telur juga mengandung asam amino yang sangat bermanfaat dalam pemulihan otot. Putih telur sangat mudah didapat, diolah dan mudah dicerna sehingga lebih mudah diserap oleh tubuh (Rindiani, 2015). Mengingat pentingnya makanan guna pemulihan dan mempercepat proses penyembuhan luka perineum, maka bidan sebagai ujung tombak pelayanan kesehatan harus mampu memberikan pengetahuan tentang diet yang benar, sehingga proses penyembuhan luka perineum dapat berjalan normal. Tujuan dalam penelitian ini adalah untuk mengetahui perbedaan efektivitas pemberian putih telur dan ikan gabus terhadap penyembuhan luka perineum pada ibu nifas di BPM Ny. S Kabupaten Kediri.

\section{METODE}

Jenis penelitian yang digunakan pada penelitian ini adalah pre-eksperimen dengan menggunakan pendekatan one-shot case study.Penelitian ini dilakukan di BPM "S" Kabupaten Kediri bulan Juni Tahun 2017. Populasi dalam penelitian ini adalah seluruh ibu postpartum hari pertama yang mengalami luka perineum derajat 1 dan 2 di BPM "S" Kabupaten Kediri. Sampel penelitian ini adalah sebagian ibu postpartum pertama yang mengalami luka perineum derajat 1 dan 2 di BPM "S" Kabupaten Kediri sebesar 32 responden dengan kriteria yaitu ibu post partum pada hari ke 1-7, belum pernah mengkonsumsi putih telur dan ikan gabus setelah melahirkan dengan luka perinuem dan ibu post partum yang tidak mempunyai riwayat alergi.
Setelah mendapat ijin dari lokasi penelitian terkait, peneliti memberikan penjelasan kepada responden lalu membuat persetujuan bila bersedia di teliti, kemudian diberikan lembar pengumpulan data. Kemudian sampel dibagi dalam dua kelompok. Kelompok perlakuan 1 merupakan kelompok perlakuan yang diobservasi penyembuhan luka perineum dengan pemberian putih telur sebanyak 139 gram (Rindiani, 2015), sedangkan kelompok perlakuan 2 merupakan kelompok yang diobservasi penyembuhan luka perineum dengan pemberian ikan gabus sebanyak 100 gram (Kordi, 2010). Sebelum peneliti melakukan perlakuan, kelompok 1 dan 2 diberikan penyuluhan tentang tentang manfaat putih telur dan ikan gabus dan cara pengolahannya.

Cara pengolahan putih telur didihkan air dalam panci. Permukaan air harus lebih tinggi dari telur, artinya telur yang direbus harus tenggelam. Setelah air mendidih masukkan telur sampai ke dasar panci. Rebus selama 7 8 menit. Angkat telur. Rendam dalam air dingin selama 5 menit, baru kupas. Berikan pada ibu bagian putih telur sebanyak 139 gram sehari selama 7 hari. Cara pengolahan ikan gabus 1). Siapkan ikan gabus segar, 2). Ikan dibersihkan/disiangi (dibuang sisik, isi perut, insang, sirip, dan kepala, 3). Ikan dipotongpotong dan ditimbang @ 100 gram, 4). Cuci hingga tidak ada darah dan lendir, 5). Ikan yang telah dibersihkan, ditiriskan. 6). Bumbuhi ikan dengan kunyit dan daun jeruk untuk memberikan rasa dan menghilangkan amis, 7). Siapkan sabluk, dan berikan air sebanyak 1 liter, 8). Setelah siap, kukus ikan selama 20 menit. 9). Berikan kukusan ikan gabus 100 gram sehari selama 7 hari. Setelah diberikan informasi, kemudian peneliti mulai melakukan perlakuan, yaitu pada pada kelompok 1 diberikan putih telur sebanyak 139 gram dan kelompok 2 diberikan ikan gabus sebanyak 100 gram. Setelah itu, pada hari ke tujuh post partum peneliti melakukan observasi penyembuhan luka perineum pada kelompok 1 dan 2. Prosedur pengumpulan data dalam penelitian ini dilakukan dengan lembar observasi yang dilakukanolehpeneliti.

Untuk menguji perbedaan efektivitas pemberian putih telur dan ikan gabus terhadap penyembuhan luka perineum menggunakan uji Mann Whitneytingkat kepercayaan 95\% dengan tingkat kesalahan $\alpha=0,05$. 


\section{HASIL}

pemberian ikan gabus lalu dianalisis perbedaan efektivitas pemberian keduanya.

Karakteristik fase penyembuhan luka perineum ibu nifas dikelompokkan menurut sesudah pemberian putih telur dan sesudah

\section{Karakteristik Fase Penyembuhan Luka Sesudah Pemberian Putih Telur}

Tabel 1. Distribusi Frekuensi Responden Berdasarkan Kecepatan Penyembuhan Luka Perineum Pada Ibu Nifas Sesudah Pemberian Putih Telur di BPM "S" Kabupaten Kediri Tahun 2017

Kriteria Penilaian Luka
Perineum

Karakteristik Fase Penyembuhan Luka Sesudah Pemberian Ikan Gabus

Tabel 2. Distribusi Frekuensi Responden Berdasarkan Kecepatan Penyembuhan Luka Perineum Pada Ibu Nifas Sesudah Pemberian Ikan Gabus di BPM "S" Kabupaten Kediri Tahun 2017

\begin{tabular}{|c|c|c|}
\hline \multirow{2}{*}{$\begin{array}{c}\text { Kriteria Penilaian Luka } \\
\text { Perineum }\end{array}$} & \multicolumn{2}{|c|}{ Kelompok Pemberian Ikan Gabus } \\
\cline { 2 - 3 } & Frekuensi & Persentase (\%) \\
\hline Buruk & 5 & $(31,2)$ \\
Sedang & 9 & $(56,3)$ \\
Baik & 2 & $(12,5)$ \\
\hline Total & 16 & $(100,0)$ \\
\hline
\end{tabular}

Hasil penelitian tersebut menunjukkan bahwa distribusi kecepatan penyembuhan luka perineum pada ibu nifas sesudah pemberian ikan gabus di BPM "S" Kabupaten Kediri tahun 2017 sebagian besar $(56,3 \%)$ sedang dengan kondisi luka masih basah, perineum tertutup, serta tidak menunjukkan tanda infeksi yaitu sebanyak 9 orang.

Analisis Perbedaan Efektivitas Pemberian Putih Telur dan Ikan Gabus Terhadap Penyembuhan Luka Perineum

Tabel 3. Analisis Perbedaan Efektivitas Pemberian Putih Telur dan Ikan Gabus Terhadap Penyembuhan Luka Perineum di BPM "S" Kabupaten Kediri Tahun 2017

\begin{tabular}{|c|c|c|c|c|c|c|c|c|}
\hline \multirow{3}{*}{$\begin{array}{l}\text { Kelompok } \\
\text { Perlakuan }\end{array}$} & \multicolumn{6}{|c|}{ Kriteria Penilaian Luka Perineum } & \multicolumn{2}{|c|}{ Total } \\
\hline & \multicolumn{2}{|c|}{ Buruk } & \multicolumn{2}{|c|}{ Sedang } & & \multirow{2}{*}{$\begin{array}{c}\text { Baik } \\
\%\end{array}$} & & \\
\hline & $\mathrm{N}$ & $\%$ & $\mathrm{~N}$ & $\%$ & $\mathrm{~N}$ & & $\mathrm{~N}$ & $\%$ \\
\hline Putih telur & 2 & 12,5 & 4 & 25,0 & 10 & 62,5 & 16 & 100 \\
\hline Ikan Gabus & 5 & 31,2 & 9 & 56,3 & 2 & 12,5 & 16 & 100 \\
\hline \multicolumn{7}{|c|}{ Total } & 32 & 100 \\
\hline \multicolumn{9}{|c|}{$\begin{array}{c}\alpha=0,05 ; Z=-2,626 ; \\
\rho \text {-value }=0,009 ; \rho<0,05\end{array}$} \\
\hline
\end{tabular}


Berdasarkan tabel 3 dapat diinterpretasikan bahwa ibu nifas dengan luka perineum yang diberikan putih telur sebagian besar $(62,5 \%)$ baik (luka sudah mengering, perineum tertutup, dan tidak menunjukkan tanda infeksi) yaitu sebanyak 10 orang, sedangkan ibu nifas dengan luka perineum yang diberikan ikan gabus sebagian besar $(56,3)$ sedang (luka masih basah, perineum tertutup, serta tidak menunjukkan tanda infeksi) yaitu sebanyak 8 orang. Hasil analisa data menggunakan uji Mann Whitney didapatkan hasil nilai $\mathrm{Z}=-2,626$ dan $\rho$-value $0,009<0,05$.

\section{PEMBAHASAN}

Lukaperineum adalah luka karena adanya robekan spontan jalan lahir maupun karena episiotomi pada waktu melahirkan janin. Luka perineum umumnya terjadi di garis tengah perineum dan bisa menjadi luas yang disebabkan apabila kepala janin lahir terlalu cepat, partus presipitatus yang tidak terkendali, paritas, terdapat banyak jaringan parut, bayi besar, malpresentasi, distosia bahu, perluasan episiotomi dan faktor penyebab lainnya. Terjadinya luka perineum ini lebih sering terjadi pada ibu yang mengalami persalinan pertama, namun tidak jarang juga pada persalinan berikutnya (Marmi, 2012).

Didapatkan hasil penelitian, seluruh responden dengan keadaan luka yang basah, perineum menutup dan terasa nyeri disesuaikan dengan keadaan awal ketika jaringan mengalami cedera terjadi vasokontriksi pembuluh darah untuk mengontrol perdarahan dengan pembentukan sumbatan trombosit dan serabut fibrin, elemen darah seperti antibodi, plasma protein, elektrolit, komplomen dan air menembus spasium vaskular selama 2-3 hari yang menimbulkan kriteria inflamasi normal antara lain ada kemungkinan pembengkakan, teraba hangat, kemerahan dan nyeri (Smeltzer, 2017).

Penyembuhan luka merupakan tahap pergantian dan perbaikan fungsi jaringan yang telah rusak dan diawali dengan perbaikan luka perineum. Proses penyembuhan luka melalui fase inflamasi yang bermula ketika jaringan mengalami kerusakkan dan berlangsung dalam 1-4 hari dimana terjadi vasokontriksi pembuluh darah untuk mengontrol perdarahan dengan membentuk sumbatan trombosit dan serabut fibrin. Selanjutnya fase proliferasi dimana terjadi pembentukan pembuluh darah baru sekitar luka, terbentuk substansi dasar dan serabut kolagen untuk mulai menginfiltrasi luka. Sel epitel berkembang menjadi kapiler yang menjadi sumber nutrisi jaringan yang beregenerasi lengkap dan kolagen menunjang dengan baik dalam kurun waktu 6-7 hari. Adapun kriteria penilaian lukanya yaitu baik (jika luka kering, perineum menutup dan tidak ada tanda infeksi seperti merah, bengkak, panas, nyeri, fungsioleosa), sedang (jika luka basah, perineum menutup dan tidak ada tanda infeksi), buruk (jika luka basah, perineum membuka atau menutup, dan menunjukkan tanda infeksi). Fase selanjutnya adalah maturasi yang dikontribusi oleh jaringan granulasi yaitu timbunan kolagen untuk penyembuhan luka yang berlangsung sampai sebulan atau bahkan tahunan (Mauren, 2008).

Menurut peneliti selain penyembuhan luka dipengaruhi oleh faktor diantaranya gizi terutama protein yang berperan untuk pergantian jaringan yaitu dengan pemberian protein putih telur dan ikan gabus, usia, pengetahuan, berat badan, personal hygiene, medikasi, paritas dan berbagai faktor lainnya juga, tindakan penanganan luka perineum diantaranya dapat dilakukan dengan cara melakukan penjahitan luka lapis demi lapis, mencegah kehilangan darah yang tidak perlu, dan memastikan tidak ada celah terbuka pada luka yang dapat dimasuki bekuan darah yang menghambat penyembuhan luka. Perawatan khusus pada perineum pasca persalinan sangat dibutuhkan antara lain untuk mengurangi rasa ketidaknyamanan, menjaga kebersihan dan mencegah terjadinya infeksi sehubungan dengan penyembuhan jaringan.

Proses penyembuhan luka perineum membutuhkan asupan nutrisi yang adekuat terutama yang banyak mengandung protein. Protein membantu meregenerasi dan membangun sel-sel yang rusak akibat operasi. Salah satu sumber makanan yang kaya akan protein adalah putih telur. Putih telur mengandung protein yang sangat tinggi, mutu protein, nilai cerna, dan mutu cerna telur paling baik diantara bahan-bahan makanan lainnya. Nilai cernanya bernilai $100 \%$ dibandingkan dengan daging yang hanya $81 \%$. Putih telur mengandung albumin 95\% yang berfungsi untuk penyembuhan luka. Protein putih telur sangat mudah untuk dicerna, diserap, dan digunakan oleh tubuh untuk 
pertumbuhan dan perkembangan jaringanjaringan tubuh (Warsito, 2015).

Perbaikan gizi merupakan salah satu kunci dari penyembuhan luka. Ibu nifas diasarankan untuk mengonsumsi makanan seimbang, cukup karbohidrat, protein, lemak, vitamin dan mineral. Faktor gizi utama protein akan sangat berpengaruh terhadap proses penyembuhan luka perineum karena pergantian jaringan sangat membutuhkan protein yang berfungsi sebagai zat pembangun sel-sel yang telah rusak. Kebutuhan protein akan meningkat dalam proses inflamasi, imun, dan perkembangan jaringan granulasi. Kolagen merupakan jenis protein utama yang disintesis selama fase penyembuhan luka. Kekurangan asupan atau intake protein saat proses penyembuhan luka, secara signifikan menunda penyembuhan luka. Salah satu sumber makanan yang kaya akan protein adalah putih telur. Putih telur mengandung protein yang sangat tinggi, mutu protein, nilai cerna dan mutu cerna paling baik dibandingkan dengan protein hewan lainnya. Protein putih telur kaya akan nutrisi diantaranya protein niacin, riboflavin, klorin, magnesium, kalium, sodium, ovalbumin dan mempunyai nilai biologis tinggi karena mengandung asam amino lengkap dibanding protein hewan lainnya (Suherni et al., 2009).

Menururt Warsito (2015), nilai cerna putih telur adalah $100 \%$ dibandingkan dengan daging yang hanya $81 \%$, oleh karena zat gizi putih telur sudah dalam keadaan terstimulasi sehingga mudah dicerna dan diabsorbsi oleh tubuh secara sempurna sehingga digunakan tubuh untuk pertumbuhan dan perkembangan jaringan-jaringan tubuh. Putih telur mengandung albumin 95\% yang berfungsi untuk penyembuhan luka. Berdasarkan hal yang dijelaskan di atas, peneliti dapat menyimpulkan bahwa protein putih telur mempunyai pengaruh terhadap penyembuhan luka dengan pemenuhan kebutuhan protein untuk pembentukan jaringan baru di sekitar luka. Meskipun banyak faktor yang mempengaruhi, tetapi menjaga asupan nutrisi protein tinggi dengan putih telur lebih dominan untuk pemenuhan kebutuhan protein dalam tubuh.

Sepuluh orang yang mengalami perubahan penyembuhan luka baik tersebut juga dipengaruhi oleh banyak faktor selain pemberian putih telur yaitu faktor usia dimana sebagian besar responden dalam masa usia 20-
35 tahun (usia reproduksi), sehingga mekanisme sel mempunyai respon lebih cepat dan bekerja lebih efektif terhadap penyembuhan luka, sebagian besar responden berpendidikan menengah sehingga lebih mudah menerima, menyaring dan merespon informasi mengenai perawatan dan nutrisi yang mendukung penyembuhan luka perineum, dan sebagian besar pula responden dengan paritas multipara sehingga ibu sudah ada pengalaman menghadapi situasi untuk pemenuhan kebutuhan nutrisi dan perawatan masa nifas.

Hasil analisis pada konsumsi ikan gabus menunjukkan adanya pengaruh pemberian ikan gabus terhadap penyembuhan luka perineum pada ibu nifas , Menurut Suprayitno (2003), daging ikan gabus mengandung $70 \%$ protein dan $21 \%$ albumin, di samping itu ikan gabus juga mengandung asam amino lengkap dalam memperbaiki jaringan tubuh yang rusakn dan mempunyai peranan untuk meningkatkan daya tahan tubuh. Kandungan albumin yang hanya $21 \%$ daya cerna ikan gabus yang lebih lama yaitu $90 \%$ menyebabkan lebih sedikit kandungan protein albumin yang mampu diserap tubuh yang berakibat pada pencapaian penyembuhan luka perineum ke arah baik menjadi lebih lama (Suprayitno, 2003).

Berdasarkan hal yang dijelaskan di atas, peneliti dapat menyimpulkan bahwa protein ikan gabus mempunyai pengaruh terhadap penyembuhan luka perineum, tetapi karena kandungan albumin yang berperan dalam penyembuhan lebih sedikit dan daya serap yang lebih rendah berpengaruh terhadap lamanya pencapaian kondisi luka yang baik.

Menurut peneliti faktor lain yang menyebabkan lebih lama tercapainya fase penyembuhan adalah faktor usia ibu, dimana hampir setengah dari responden usia >35 tahun, yang berati semakin usia bertambah, luka akan semakin lama sembuh ini dikarenakan mekanisme sel dalam penyembuhan luka mempunyai respon lebih lambat. Selain itu, hampir setengah dari responden dengan kategori berat badan gemuk yang berpengaruh terhadap lamanya penyembuhan luka karena jaringan adiposa atau lemak yang berlebihan dapat menghalangi suplai darah dan nutrisi ke arah luka sehingga luka lama sembuh dan mudah infeksi.

Penyebab lain juga karena paritas, dimana hampir setengah responden adalah primipara yang memungkinkan ibu kurang 
pengalaman mengenai pemenuhan kebutuhan nutrisi protein yang tepat dan perawatan masa nifas yang benar sehingga berpengaruh pada lambatnya penyembuhan luka perineum.Hal ini juga didukung Hasil penelitian sebelumnya yang dilakukan oleh Maria Natalia (2015) menunjukkan bahwa ibu post SC yang diberikan ikan gabus sebagian besar tidak tercapai fase penyembuhan luka.

Hasil penelitian didapatkan bahwa ibu nifas dengan luka perineum yang diberikan putih telur sebagian besar $(62,5 \%)$ baik (luka mengering, perineum tertutup, dan tidak menunjukkan tanda infeksi) yaitu sebanyak 10 orang, sedangkan ibu nifas dengan luka perineum yang diberikan ikan gabus sebagian besar $(56,3)$ sedang (luka masih basah, perineum tertutup, serta tidak menunjukkan tanda infeksi) yaitu sebanyak 8 orang.

Masa nifas (postpartum) merupakan periode kritis baik bagi ibu maupun bayinya, sehingga seorang ibu yang mengalami fase nifas membutuhkan perawatan khusus untuk memperbaiki kondisi kesehatan tubuhnya termasuk dengan perhatian terhadapat penyembuhan luka perineum dengan perawatan dan meningkatkan asupan nutrisi terutama protein ${ }^{22}$ hal ini penting dilakukan karena apabila luka tersebut tetap terbuka maka akan menjadi jalur masuknya kuman yang dapat menyebakan infeksi.

Kecukupan gizi dan nutrisi terutama protein sangat mempengaruhi proses penyembuhan luka perineum karena diperlukan untuk pergantian jaringan yang rusak, karena pada kejadian perlukaan, banyak nitrogen yang dilepas ke dalam urin dan banyaknya sesuai dengan protein yang hilang dan meningkatkan kebutuhan energi. Pemenuhan kebutuhan protein diperlukan karena hasil sintesis protein bermanfaat untuk menggantikan dan memperbaiki jaringan yang rusak. Protein yang paling berperan yaitu albumin. Albumin ialah protein utama dengan konsentrasi paling tinggi dalam plasma darah yang terdiri dari ratusan asam amino dan ikatan sulfide. Albumin berperan dalam membentuk dan mempercepat pemulihan jaringan sel tubuh yang rusak (Mauren, 2008).

Ada kelompok perlakuan yang diberikan putih telur sebanyak 139 gram perhari selama 5-6 hari dan ada kelompok perlakuan yang diberikan ikan gabus sebanyak 100 gram perhari selama 5-6 hari bertujuan agar kebutuhan protein dan albumin yang dibutuhkan dapat terpenuhi sehingga membantu mempercepat proses penyembuhan luka perineum sehingga hasil observasi yang diperoleh setelah pemberian menunjukkan kondisi luka kering, perineum menutup dan tidak ada tanda infeksi (merah, bengkak, panas, nyeri).

Hasil analisa data menggunakan uji Mann Whitney didapatkan hasil nilai $\mathrm{Z}=$ 2,626 dan $\rho$-value $0,009<\alpha 0,05$ menunjukkan adanya perbedaan efektifitas pemberian putih telur dan ikan gabus terhadap penyembuhan luka perineum, dimana putih telur lebih efektif daripada ikan gabus terhadap penyembuhan luka perineum pada ibu nifas. Jadi baik putih telur dan ikan gabus sama mempunyai pengaruh dalam proses penyembuhan luka perineum karena kandungan protein pada putih telur dan ikan gabus. Akan tetapi putih telur lebih memberikan efek yang cepat bagi penyembuhan luka perineum.

Hal ini disebabkan karena putih telur mengandung lebih banyak protein albumin (95\%) dibandingkan kandungan albumin pada ikan gabus yang lebih sedikit $(21 \%)$, dimana kandungan albumin yang membantu proses pergantian dan perbaikan fungsi jaringan yang rusak. Selain itu, nilai cerna protein putih telur mencapai $100 \%$, dimana kandungan protein putih telur sebagai protein bernilai gizi tinggi diserap dan dimanfaatkan utuh oleh tubuh sebagai sumber nitrogen untuk sintesis protein yang dimanfaatkan untuk pembentukan jaringan baru, serta putih telur mempunyai kandungan asam amino esensial yang lengkap dibandingkan ikan gabus dengan nilai cerna $90 \%$.

Banyak hal yang dapat mempengaruhi penyembuhan luka itu sendiri. Dalam beberapa penelitian disebutkan faktor yang mempengaruhi kecepatan penyembuhan luka perineum adalah usia, keturunan, sarana dan prasarana, budaya dan keyakinan mobilisasi dini, nutrisi dan penggunaan obat (Johnson dan Taylor, 2005) Namun dalam penelitian ini faktor yang mempengaruhi penyembuhan luka berdasarkan karakteristik responden adalah usia, kategori berat badan, pendidikan dan paritas.

Menurut peneliti selain faktor nutrisi, proses penyembuhan luka juga dipengaruhi oleh beberapa faktor lain diantaranya yaitu faktor usia dimana ibu nifas dengan luka perineum berada dalam usia reproduksi (20-35 tahun) memiliki mekanisme sel yang bekerja 
lebih cepat dan efektif terhadap penyembuhan luka. Sedangkan pada usia $>35$ tahun mekanisme sel memiliki respon yang lambat sehingga waktu yang dibutuhkan untuk penyembuhan luka menjadi lebih lama dan kurang efektif. Tingkat pendidikan yang tinggi cenderung pengetahuannya baik. Hal tersebut disebabkan karena ibu memiliki wawasan yang luas sehingga lebih mudah menerima informasi dan bisa menyikapi masalah kesehatan dengan baik dan mampu mengimplementasikan dalam perilaku dan gaya hidup sehari-hari. Sedangkan pengetahuan ibu yang kurang menyebabkan ibu sulit menerima dan mengimplementasikan informasi mengenai perilaku hidup sehat serta menjadi mudah dipengaruhi oleh orang lain atau lingkungan sekitar. Pengetahuan ibu yang kurang tentang nutrisi dan perawatan masa nifas akan menghambat proses penyembuhan luka.

Kategori berat badan juga berpengaruh terhadap penyembuhan luka perineum. Menurut peneliti, berat badan normal memungkinkan suplai darah dan nutrisi ke area luka menjadi lancar sehingga mendukung proses penyembuhan luka, sedangkan responden dengan berat badan berlebih menyebabkan pertahanan terhadap mikroba sangat lemah dan mengganggu suplai nutrisi ke arah luka, akibatnya penyembuhan luka menjadi lambat.

Menurut peneliti faktor paritas juga berpengaruh, ibu yang sudah mempunyai anak atau yang sudah pernah melahirkan seperti halnya ibu multipara akan berbeda dengan apa yang dirasakan atau dialami orang yang baru pertama melahirkan (primipara) karena pengalaman menghadapi situasi tersebut akan membuat seseorang lebih siap dan mandiri dalam melakukan pemenuhan kebutuhan nutrisi pasca melahirkan.

\section{KESIMPULAN}

Berdasarkan hasil penelitian dapat disimpulkan bahwa pemberian putih telur lebih efektif daripada pemberian ikan gabus terhadap penyembuhan luka perineum pada ibu nifas di BPM "S" Kabupaten Kediri.

\section{SARAN}

Memberikan sosialisasi kepada ibu post partum yang mempunyai luka jahitan agar selalumengonsumsiputihtelursehingga proses penyembuhanlebihcepat.

\section{DAFTAR PUSTAKA}

Ambarwati dan Wulandari. 2010. Asuhan Kebidanan Nifas. Yogyakarta: Nuha Medika.

Dwi, Y. 2014. Pengaruh Penggunaan Daun Sirih (Piper Betel) Untuk Vulva Hygien Terhadap Proses Penyembuhan Luka Episiotomi Pada Ibu Nifas Hari Ke 1-7 Di Wilayah Kerja Puskesmas. Fakultas Ilmu Kesehatan Universitas Kadiri.

Johnson, Ruth, dan T. W. 2005. Buku Ajar Praktik Kebidanan. Penerjemah: Suharyati Samba. Editor: Sari Kurniasih, Monica Ester. Jakarta: EGC.

Kordi, M. G. H. 2010. Panduan Lengkap Bisnis dan Budi Daya Ikan Gabus. Edisi I. Yogyakarta: ANDI.

Marmi. 2012. Intranatal Care-Asuhan Kebidanan Pada Persalinan. Yogyakarta: Pustaka Pelajar.

Mauren, B. 2008. Pemulihan Luka: Seri Praktik Kebidanan. Jakarta: EGC.

Nugroho, T. 2014. Buku Ajar Asuhan Kebidanan Nifas (Askeb 3). Yogyakarta: Nuha Medika. doi: 10.1016/j.hrthm.2014.11.036.

Rindiani. 2015. Khasiat Putih Telur untuk Penyembuhan Luka. Yogyakarta: Nuhamedika.

Setyowati, D. L., Shaluhiyah, Z. and Widjasena, B. 2014. Penyebab Kelelahan Kerja pada Pekerja Mebel. Kesmas: National Public Health Journal, 8(8), pp. 386-392. doi: 10.21109/kesmas.v8i8.409.

Smeltzer, S. C. 2017. Keperawatan Medikal Bedah (Handbook for Brunner \& Suddarth's Textbook of MedicalSurgical Nursing). Wolters Kluwe healthr.

Suherni et al,. 2009. Perawatan Masa Nifas. Yogyakarta : Fitramaya.

Suprayitno, E. 2003. Potensi Serum Albumin dari Ikan Gabus.

Warsito, H. et al., 2015. Ilmu Bahan Makanan Dasar. Yogyakarta: Nuha medika.

Winarti. 2013. Angka Kejadia Ruptur. 